\title{
Erratum to: Weakly periodic boundary conditions for the homogenization of flow in porous media
}

\author{
Carl Sandström*, Fredrik Larsson and Kenneth Runesson
}

* Correspondence:

carl.sandstrom@chalmers.se

Department of Applied Mechanics,

Chalmers University of Technology,

Hörsalsvägen 7, 41296 Göteborg,

Sweden

\author{
Abstract \\ No abstract. \\ Erratum \\ After publication of the original article [1] it came to the Publisher's attention that the \\ first author's name had been listed incorrectly. The list of authors has now been \\ corrected. We apologise for any inconvenience this has caused. \\ Received: 11 March 2015 Accepted: 11 March 2015 \\ Published online: 30 April 2015

\section{Reference} \\ 1. Sandström C, Larsson F, Runesson K (2014) Weakly periodic boundary conditions for the homogenization of flow \\ in porous media. Adv Model Simul Eng Sci 1:12
}

(C) 2015 Sandström et al.; licensee Springer. This is an Open Access article distributed under the terms of the Creative Commons Attribution License (http://creativecommons.org/licenses/by/4.0), which permits unrestricted use, distribution, and reproduction in any medium, provided the original work is properly cited.
Submit your manuscript to a SpringerOpen ${ }^{\odot}$ journal and benefit from:

- Convenient online submission

- Rigorous peer review

- Immediate publication on acceptance

- Open access: articles freely available online

- High visibility within the field

- Retaining the copyright to your article

Submit your next manuscript at springeropen.com 